
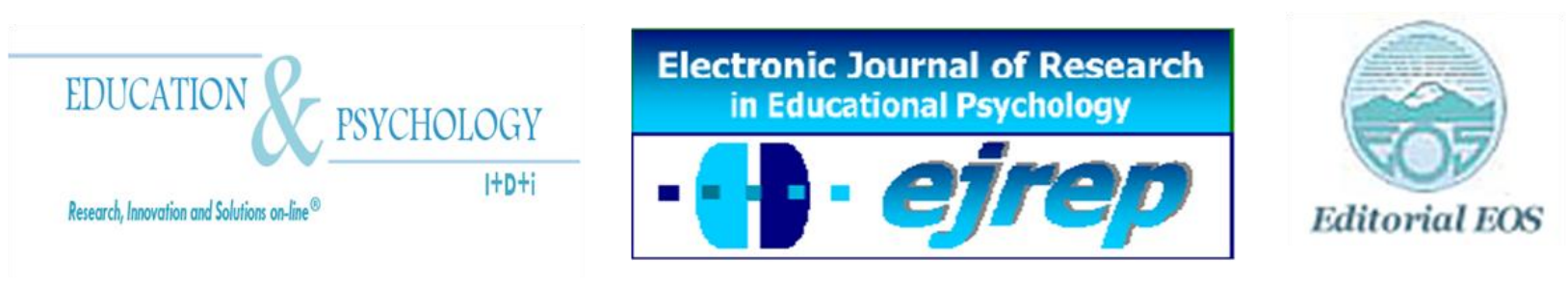

\title{
Impact of Facebook Usage on Students' Academic Achievement: Roles of Self-Regulation and Trust
}

\section{Sana Rouis $^{1}$, Moez Limayem ${ }^{2}$, Esmail Salehi-Sangari ${ }^{3}$}

\author{
${ }^{1}$ Industrial Marketing and e-Commerce Research Group, Business \\ Administration, Technology and Social Sciences Department, Luleå University \\ of Technology, Luleå \\ ${ }^{2}$ Department of Academic Affairs, Sam M. Walton College of Business, \\ University of Arkansas, Fayetteville \\ ${ }^{3}$ Department of Industrial Economics and Management (INDEK), Royal \\ Institute of Technology, Stockholm and Industrial Marketing and e-Commerce \\ Research Group, Business Administration, Technology and Social Sciences \\ Department, Luleå University of Technology, Luleå
}

\section{SWEDEN-USA}

Correspondence: Sana Rouis Industrial Marketing and e-Commerce Research Group, Business Administration, Technology and Social Sciences Department, Luleå University of Technology, SE-971 87 Luleå Sweden. Email: sana.rouis@1tu.se

(C) Education \& Psychology I+D+i and Editorial EOS (Spain) 


\section{Abstract}

Introduction. This paper provides a preliminary analysis of the effects of Facebook usage by undergraduate students at Luleå University of Technology in Sweden. The proposed research model tests the perceived effect of personality traits, self-regulation, and trust on students' achievements. On the basis of flow theory, the model suggests negative mediating effects of the use of and cognitive absorption on Facebook; it leads to a decrease in students' academic performance but a positive effect on satisfaction with life that limits the undesirable effect.

Method. Data from paper-and-pencil surveys with 239 undergraduate students from Luleå University of Technology were used to test the model. SmartPLS software was employed to test the proposed structural equation model.

Results. The results indicate that extensive use of Facebook by students with extraverted personalities leads to poor academic performance. However, students who are more self-regulated control their presence on these platforms more effectively. Trust in people does not influence their presence and interaction on the platform. Students' cognitive absorption with Facebook is regulated only by their self-control and personality traits, which determine how much time they spend on Facebook. Multitasking skills moderate the effect of cognitive absorption on academic achievement, but they do not impede the time spent, frequency, or nature of use or their effect on academic results. Although students' satisfaction with life significantly declines due to cognitive immersion with Facebook, it does not play a role for students' academic achievement. However, their performance goal orientation is a crucial determinant of university accomplishments, which would limit the critical effect of their presence on the Facebook platform.

Discussion and Conclusion. The results partly support prior conclusions about the personality traits that determine presence on Facebook. Trust does not impede Facebook usage but determines use of the Internet. Self-regulation and performance goal orientations characterize students who are more in control of their social activity, which in turn limits the apparent negative effect on their academic performance. These results should help students understand the consequences of their extensive usage of Facebook and better manage their social activities on this platform.

Keywords: Facebook usage, academic achievement, cognitive absorption, self-regulation, trust, personality traits, satisfaction with life.

Received: 08/30/2011 Initial acceptance: 09/28/11 Final acceptance: 11/08/11 


\section{Impacto del uso de Facebook en el rendimiento de los estudiantes: El papel de la Autorregulación y la Confianza}

\section{Resumen}

Introducción. Este trabajo ofrece un análisis preliminar sobre los efectos del uso de Facebook en los estudiantes universitarios de la Universidad de Tecnología Luleå, en Suecia. El modelo de investigación propuesto examina el efecto percibido de los rasgos de personalidad, la autorregulación y la confianza sobre el rendimiento de los estudiantes. Basándonos en la teoría del flow, el modelo sugiere efectos mediadores negativos y absorción cognitiva por el uso de Facebook, concluyendo que existe una disminución en el rendimiento académico de los estudiantes, pero un efecto positivo sobre la satisfacción vital, la cual limitaría este efecto no deseable.

Método. Se administró una encuesta en soporte impreso a estudiantes universitarios de la Universidad de Técnología Luleå, y se emplearon los datos de 239 estudiantes para probar el modelo. Se utilizó el software SmartPLS para comprobar el modelo de ecuaciones estructurales propuesto.

Resultados. Los resultados indicaron un abundante uso de Facebook por estudiantes de personalidad extrovertida, lo cual llevaba a un rendimiento académico pobre. Sin embargo, los estudiantes más autorregulados controlaron más eficazmente su presencia en estas plataformas. La confianza en las personas no afectaba su presencia ni su nivel de interacción en esta plataforma. La absorción cognitiva de los estudiantes con Facebook sólo se regulaba por su autocontrol y sus rasgos de personalidad, los cuales determinaban cuánto tiempo dedicaban a Facebook. La capacidad de realizar varias actividades a la vez (multitasking) modera la incidencia de la absorción cognitiva en el rendimiento académico, pero no impide el tiempo dedicado, la frecuencia o la naturaleza del uso o su incidencia en los resultados académicos. Aunque la satisfacción vital de los alumnos decreció de manera significativa debido a la inmersión cognitiva en Facebook, no parecía desempeñar un papel eficaz en el rendimiento académico de los alumnos. Sin embargo, se mostró que su orientación de meta al rendimiento era un determinante crucial de su rendimiento universitario, lo cual limita el efecto crítico de su presencia en la plataforma de Facebook. 
Discusión y Conclusiones. Los resultados respaldan en parte otras conclusiones anteriores sobre los rasgos de personalidad que rigen la presencia en Facebook. La confianza no impide el uso de Facebook tal como determina el uso de Internet de los navegantes. Los estudiantes que tienen más control sobre esta actividad social se caracterizan por la autorregulación y la orientación de meta al rendimiento. Éstas, a su vez, evitan el efecto aparentemente negativo en su rendimiento académico. Los resultados sirven para que los estudiantes entiendan mejor las consecuencias preliminares de un abundante uso de Facebook, y para que gestionen mejor sus actividades sociales en esta plataforma.

Palabas clave: uso de Facebook, rendimiento académico, absorción cognitiva, autorregulación, confianza, rasgos de personalidad, satisfacción vital. 


\section{Introduction}

Facebook has attracted considerable attention among researchers. As a social networking site, it offers an online platform on which users create profiles, generate and share contents and information, and interact with other known and unknown contacts (Boyd and Ellison, 2007). Facebook also has experienced vast expansion in recent years, leading to its extensive use by people from all generations. Its 661.3 million users represent annual growth of 45.2\% (Inside Facebook Gold, 2011), while its business value has surged to US\$50 billion after an investment by Goldman Sachs in early 2011.

Several studies examine the attraction and persuasive character of this online platform and similar networking sites (e.g., Fogg and lizawa, 2008), as well as the reasons that cause people from all walks of life and age ranges to join this community or similar options. Many people actively participate in content generation and value creation, and several researchers (e.g., Young et al., 2009; Vasalou et al., 2010) have examined their profiles to determine why and to what extent they are keen on posting their entire identity, sharing pictures and videos, and indicating their religious affiliations, marital status, and political orientations on the Internet. These users interact with others, exchange information about their interests, raise discussions about news topics, follow news about specific topics on Twitter, and enjoy sharing private videos on YouTube. However, few studies examine the return on these investments in the networks, whether for the companies for the individual users who post. Some studies suggest that these platforms likely support social capitalization and increase interactions in a community of others with common traits and interests, as demonstrated by Facebook (Burke et al., 2010; Ellison et al., 2007, 2011; Ginger, 2007; Yoder and Stutsman, 2011).

Other exploratory studies (Canales et al., 2009; Karpinski and Duberstein, 2009) also show that an extended presence on Facebook can have harmful effects on productivity and task performance. Long hours spent on Facebook seem to decrease students' academic performance and thus their grades. Students spend an average of 30-35 minutes per day surfing Facebook (Schulten, 2009b); students note that they actually spend only 3-4 minutes on each visit to check updates but make several visits a day. Others acknowledge spending up to 8 hours a day on the website. Even though they consider the website distracting and time consuming, these students note that they cannot quit visiting it, because they like it and use it 
to keep in contact with their friends and family, whether they encounter them every day or not (Facebook, 2011, Adan, 2011). Some people recognize that they "have outsourced their social life exclusively to Facebook" (Schulten, 2009a, p.1) or note feeling that using Facebook means allowing this application to take over their daily lives, which leads them to reject the platform. However, some users assert that they have become more organized since putting their profile on Facebook, primarily with regard to contact management and information sharing (Schulten, 2009b). A recent study also questions the assumed negative effects of Facebook usage on students' academic achievements and suggests instead that this interdependency is moderated significantly by students' interest in the university and multitasking capabilities (Rouis, 2012).

These controversial results, in addition to data from Facebook and students' comments on different Facebook groups, indicate that students with particular profiles focus on bridging social networks, keeping in touch with old contacts, and developing new friendships. Some students likely spend more time than others on the social network; they also should be more immersed in related tasks during the long hours they spend surfing the website, so they likely are distracted from any tasks performed in parallel. For example, users likely share information with their contacts (i.e., "friends"), participate in discussions, and upload or watch videos and pictures. Students and other active users engage in long discussions about daily issues, checking their Facebook profiles from home and cell phones. Students also check updates while preparing their homework, which interferes with their preparation. They are distracted from their main occupation, and their working memory load allocated to these tasks makes it difficult for them to be focused and prepare their homework effectively. This scenario should lead to poorer results and decreased global achievements.

However various users participate in networking activities differently, depending on their personalities and cultural backgrounds. Several studies note people's Internet-related attitudes; their interests and activities vary with their age, gender, and personality traits (Hofstede and Hofstede, 2005; Nazir et al., 2009). Cultures are delineated by the relevant countries' history, politics, and socio-economic situations. Cultural background also influences people from that culture through social learning processes and human natures, which shape their common characteristics. Each person is associated with a group of others who represent their native region; yet interacting with the external environment and communities contributes to modeling characteristics that subsequently affect attitudes and 
behaviors (Hofstede and Hofstede, 2005; Nazir et al., 2009). Differences in cultural backgrounds and characteristics suggest a need to address the impact of students' Facebook usage in various settings, which prompts questions about the unpredictability of the effect of Facebook among students with different characteristics and in different cultural contexts.

We address this question in a diverse context with students from a European country with different cultural contexts, focusing on key preliminary determinants in online interactions - namely, personality traits, trust in people, and the psychological characteristic of self-regulation. This study therefore attempts to answer the following research question: Does Facebook usage damage students' academic results in a Swedish context? The main objective is to understand students' usage of Facebook and its impact on their academic performance, through an assessment of the role of personality traits, trust in people, and selfregulation, and thereby to delineate the use of and cognitive absorption on Facebook, as well as to observe whether the usage varies in this European context. Therefore, we review a theoretical background and depict the proposed research model before we present the methodology adopted to test the model. From our analysis of the results, we draw conclusions and make recommendations for further research.

\section{Flow Theory (FT)}

Borrowed from psychology, flow theory helps assess human-computer interactions and addresses people's use of the Internet. Flow, as defined by Csikszentmihalyi (1977, p36), is the "holistic sensation that people feel when they act with total involvement." It implies absorption in a task, such that the person is completely attracted by the artifact and the task being performed. Websites, e-mail tools, and the computer itself are all artifacts; the tasks refer to an assignment performed using these tools (Finneran and Zhang, 2003). Thus Facebook is an artifact, and people using this network engage in tasks that prompt their flow on the platform. Novak et al. (1998) also provide an extensive review of the definition of flow as experienced by people immersed in a task. Described as total concentration and deep involvement in the tasks, these activities result in intrinsic enjoyment, combined with keen curiosity and pleasure that encourages repetition of the activity, but also the loss of time and an inability to control usage or halt the activity. 
Considerations of flow span several contexts, such as students' engagement in the classroom (Shernoff et al., 2003), learning of a foreign language (Egbert, 2004), management of sports and music leisure activities (Custodero, 2002; Jackson, 1977; O'Neill, 1999a, 1999b;), customers' online shopping behavior (Koufaris, 2002; Pace, 2004; Smith and Sivakumar, 2004), people's behavior and acceptance of messages and content exchanges online ( $\mathrm{Lu}$ et al., 2009), and motivation and creativity (Csikszentmihalyi and Csikszentmihalyi, 1988). Although the current stream of interactions and content generated on Facebook are similar to other online and offline activities, the number of hours that users spend is increasing, and many people claim to organize their lives about Facebook. Professionals are creating profiles, updating messages, and uploading videos to provide fans with information; fans follow the news on profile pages.

People by nature are curious (Hofstede, 2010), and Facebook also provides farreaching information through one interface, namely, individual "walls." The flow of information shared on these "walls" increases with the size of the user's network (i.e., number of "friends" and groups). Consequently, a user's attraction to and involvement in activities on the social platform likely means greater concentration and time spent following updates and news. Information shared also pertains to all areas of daily life, which makes websites such as Facebook a mine of information that anyone can explore and enlarge.

Although users experience delight and enjoyment when interacting with others on these networks and appear to be in total command of this activity, they may lose control over other tasks that they are expected to perform. Time flies while they are absorbed in the joy and curiosity produced by these websites, and no time or effort is left to conduct other tasks.

\section{Distraction Effect}

Although the use of social networking platforms is subject to the persuasive attitude of the social website and the attitudes of users toward social networking in general (Fogg and Iizawa, 2008), online behaviors also reflect personality traits, values, and cultures (Hofstede, 1984). The way people use online social networks - especially in terms of their behavioral patterns and attitudes toward information sharing and privacy-is a direct result of and reflection on their cultural backgrounds (Kiesler, 1997). 
Intellectual capabilities to manage time and process information also should affect their capacity to benefit from online activities and restrict their efficiency on any tasks performed in parallel. Facebook users usually interrupt their work to visit Facebook profiles, because of the short-term capacity needed for the working memory process. Unemployed people might go online to look for job opportunities and end up interacting on social platforms, ultimately spending much more time on them than expected. This split attention paid to multiple tasks causes distraction.

The use of online social networks also varies across countries, because cultures induce diverse impacts on their members. Absorption in the social networking activity entails extended immersion in these websites, enjoyment while interacting, and curiosity, but people are also temporally disassociated from their main tasks - whether online or offline - and lose control over their main activity in favor of chatting or checking new updates. To observe the effect of Facebook usage on students' academic performance, as well as the preliminary effect of an extensive presence on these networks, we measure Facebook usage and its impact for students in Sweden, a European context with a unique study environment and life settings.

\section{Research Model}

On the basis of the preceding theoretical background, the proposed research model posits that people's self-regulation, personality traits, and trust determine their use of Facebook. Cultural characteristics explain students' trust online (Doney et al., 1998; Jarvenpaa et al., 1999, 2000; Teo and Liu, 2007; Yoon, 2002), self-regulation attitude (Posner and Rothbart, 1998; 2000; Barkley, 2001), and personality traits (Hofstede and Hofstede, 2005; Nazir et al., 2009), which should explain the variability of Facebook usage and ultimately variability in the outcomes of such usage. In addition, the model suggests that Facebook usage has a negative impact on students' school achievements as cognitive absorption in Facebook increases, because that cognitive absorption distracts from the main task of studying or homework preparation and impedes students' concentration on their assignments.

However, we presume that life satisfaction and high performance goal orientation mitigate the crucial effect of social media usage on academic performance. Similarly, we hypothesize that students skilled in multitasking experience lower cognitive absorption than 
monochromic students, which may be less harmful for their grades. Figure 1 depicts the research model, after which we discuss the underpinnings of each assumption.

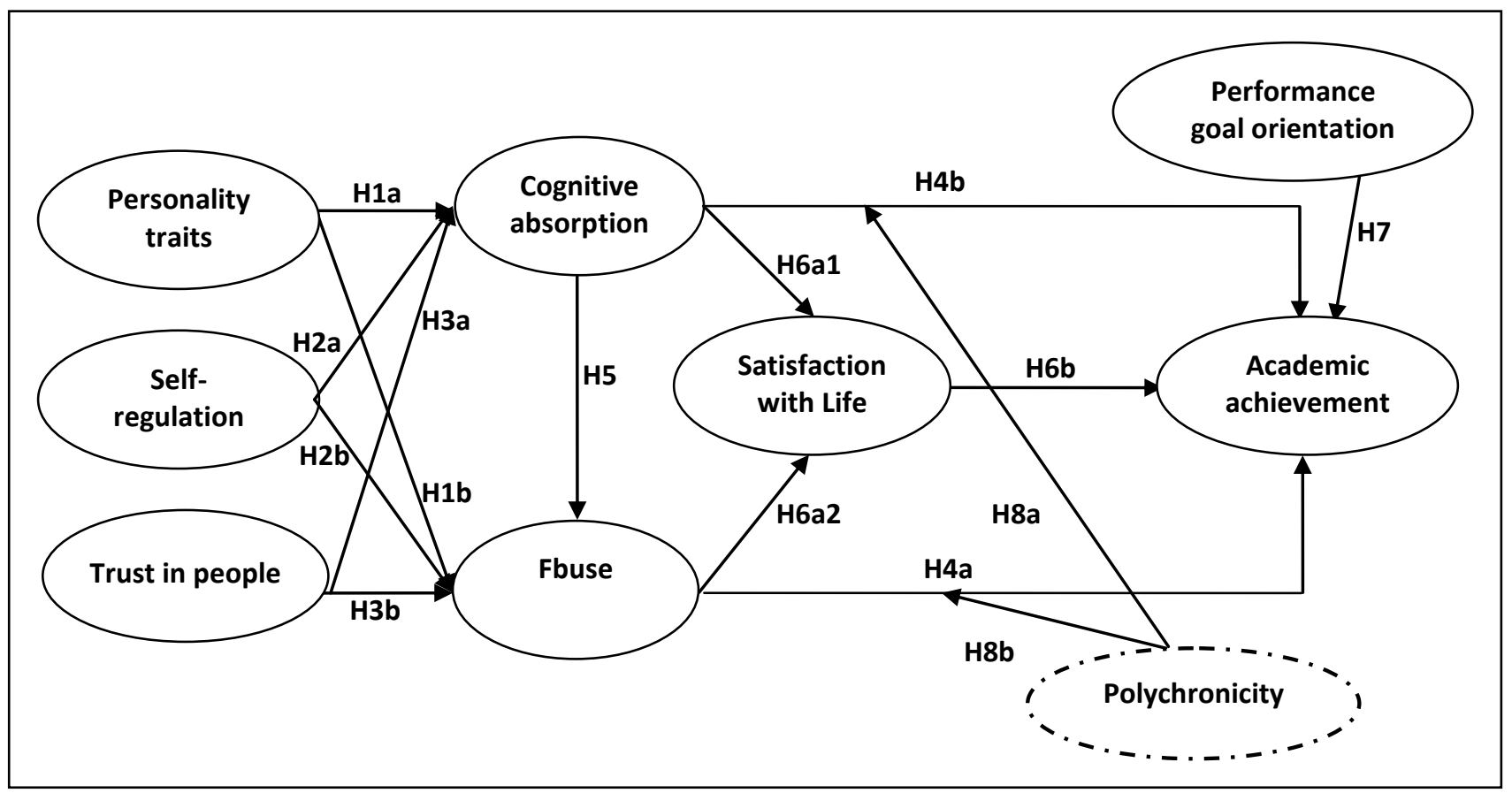

Figure 1: Research Model

Who uses Facebook?

\section{Personality traits}

Previous literature has demonstrated that personality traits reflect attitudes and represent people's predispositions to perform specific activities or exhibit particular behaviors (Ajzen and Fishbein, 1977; Daevaraj et al., 2008). Personality traits are the characteristics that, along with values, shape people's identities and form their attitudes (Olver and Mooradian, 2003; Roccas et al., 2002). Such traits originate from a psychological state and reflect the moral status, preferences, and goals of each individual. They also indicate the level of individuals' need to interact with others and inner motives and goals, such as increasing self-esteem or meeting an emotional need (Hardie and Tee, 2007).

Personality traits have been discussed extensively to explain people's online behavior, students' attitude toward education, and the impact on their academic performance (Blickle, 1996; De Raad and Schouwenburfg, 1996; Furnham et al., 2003; Hardie and Tee, 2007; Poropat, 2009). Furnham et al. (2003) and Lounsbury et al. (2005) argue that personality also 
is associated with cognitive abilities. Conscientious students tend to be more intelligent; neurotic students seem less intelligent, though that might be just an illusion. Conscientious students, aware of the importance of excelling in their studies, are likely to be more studious and diligent. Neurotic students are emotionally more sensitive, which makes them less inclined to study when they are not satisfied. They need satisfactory interpersonal interactions and entertainment, and they likely are selective of the content they check online, as they constantly try to find more opportunities to interact with and share interests with others.

Extraverted students are outgoing, with their sociable character may affect their attitudes. Judge et al. (1999, p.5) assert that "extraversion is thought to consist of sociability." Students with this personality trait are very active in social networks and highly proficient at initiating and managing groups of people on online platforms. They are talented in starting discussions of new and popular topics. People with such characteristics also are adventurous, dominant, and ambitious, which gives them skills to lead group discussions with people that they may have never met. Considering the nature of the activity on Facebook, they likely spend long hours managing groups and discussions, updating groups profiles, and uploading news, videos, and pictures to enliven debates. Agreeable Facebook users like to help others and often spend time assisting them (Kamdar and Van Dyne, 2007; Tabak et al., 2009). They are kind and honest; others like to talk to them and involve them in discussions (Clark and Schroth, 2010). Because of their courtesy, they will not decline invitations to become friends, have a look at profiles, or join a discussion.

Finally, open students are open minded (Roccas et al., 2008), intellectual, and willing to try new experiences (Judge et al., 1999). Students with this profile are curious, but their interactions online pursue new opportunities and intellectual utility. Broad minded and sensitive to art (Propat, 2009), they are imaginative and constantly look for creativity (Judge et al., 1999; Propat, 2009; Robbins and Judge, 2011).

Because these personality traits shape individual attitudes and behaviors, we hypothesize that they also determine Facebook usage, and we test the following hypotheses:

Hla: Extraverted, neurotic, and agreeable students and students open to new experiences exhibit a high presence on Facebook; conscientious students have a limited presence.

$H 1 b$ : Extraverted, neurotic, and agreeable students and students open to new experiences are highly cognitively immersed in Facebook; conscientious students are less absorbed. 


\section{Self-regulation}

Self-regulation is associated with conscientiousness (Posner and Rothbart, 1998) and may have a restrictive effect on Facebook usage. Students with high self-regulation likely allocate less time to social networks and maintain more organized attitudes toward such platforms. Their reflection on interactions on Facebook for example or content generated by the online communities are more effective. They think in terms of the "utility" of the interaction they might have, rather than using an affective basis. Although relationships are determined by cognitive and emotional motives, self-regulated people evaluate their attitudes by managing their emotional reactions to what they achieve through social activity (Bagozzi, 1992). Yet self-regulated students are also goal oriented: They set goals and strive to achieve them (Latham and Locke, 1991). We thus hypothesize that self-regulation slows the frequency of usage and reduces the number of hours spent on online networking sites.

$H 2 a$ : Highly self-regulated students exhibit less use of Facebook.

$H 2 b$ : Highly self-regulated students exhibit less cognitive absorption in Facebook.

\section{Trust in people}

Trustworthiness in online transactions and Internet-based applications has been widely discussed (Grabner-Kräuter and Kaluscha, 2003; Grandison and Sloman, 2000; Kangas et al., 2007; Wang and Emurian, 2005). In interactions on social websites, trust relates more to trust in people than in the applications. People engaged on different social networking activities give the impression that they trust almost every message, video, or picture posted. Information has many sources, and if people trust information provided, it implies that they also trust the source: They "like" the source page on Facebook, add a friend, or add people to their networks of common interests. However, many other people maintain passive profiles, with a limited number of contacts and little or no content sharing. Online social behavior thus depends on their trust in people (Golbeck, 2009), though Uslaner (2000) argues that trust sometimes does not matter in online social interactions. We hypothesize though that trust matters with increasing participation, activity, and absorption on social networking websites, because it reflects a self-conviction about the need to share this content. Thus, we test the following hypotheses: 
H3a: A high level of trust in people increases Facebook use.

$H 3 b$ : A high level of trust in people increases Facebook absorption.

\section{Facebook use}

Facebook usage encompasses both the simple use of the platform and the extent of cognitive immersion into the site. Its use implies the presence of individual users on the social website, time spent on this platform, frequent visits, and the nature of the activities performed. People from different age ranges interact and exchange content; they share videos and pictures, discuss subjects, chat, publish advertisements for group events, or play available applications. Younger generations (e.g., students) spend many hours - up to 8 per daysurfing this socializing website. We presume that an extensive presence on Facebook and the resulting increased levels of information flow management required engage students in this task more than in their homework, which deflects their attention from their main (academic) tasks while they engage in constant interactions and socialization, which prohibit them from focusing appropriately on their academic tasks. Then, we hypothesize:

H4a: Significant use of Facebook decreases students' academic achievement.

\section{Cognitive absorption}

Cognitive absorption refers to the appeal of the platform and the tasks performed there. It can reveal the extent to which a user enjoys him- or herself (Agarwal and Krahannal, 2000) during computer interactions on Facebook. The user is mentally absorbed in the online social networks, then interacts with and builds relationships through these platforms. Mentally absorbed, users become immersed and captivated by tasks that engage most of their mental efforts. Thus, the cognitive load generated to perform a particular task, which refers to the working memory resources deployed, is highest when users are fully engaged. In turn, high immersion in one task likely takes concentration away from other tasks performed in parallel. We assume that a high level of engagement in social networking activity causes students to lose focus on academic tasks and affects their academic results. We test the following hypothesis: 
$H 4 b$ : A high level of cognitive immersion on Facebook decreases students' academic achievement.

Furthermore, being absorbed in this task, users spend more time interacting with peers. Thus,

H5: A high level of cognitive absorption in Facebook increases students' time spent on the website.

Role of satisfaction with life and performance goal orientations

\section{Satisfaction with life}

Satisfaction with life has been largely discussed as a feature of positive psychology, as well as an enhancer of students' academic achievement (Chow, 2010; Danielsen et al., 2009; Huang and Carleton, 2003; Huebner, 2004; Suldo et al., 2006, 2008). However, other authors contest this assumption, because empirical studies cannot confirm this interdependence (Bastian et al., 2005; Leung and Leung 1992). Previous literature has shown that satisfaction with life depends notably on a person's relationships with his or her parents (Danielsen et al., 2009, González et al., 2010; Huebner, 2004) and friends (Huebner et al., 1998, González et al., 2010), as well as by leisure activities (Chen et al., 2010). Life satisfaction offers assistance, enabling students to prioritize concerns related to academic achievement and focus on efforts to perform well in their studies.

We assume that high usage of Facebook increases users' satisfaction with life, in that it represents a primary modern leisure activity. It also is a communication tool that students use often to keep in touch with their friends and family members. Thus, we hypothesize:

H6a: High use of Facebook increases students' satisfaction with life.

$H 6 b$ : A high level of cognitive absorption with Facebook increases students' satisfaction with life.

H6c: Students' high satisfaction with life increases their academic achievements. 


\section{Performance goal orientation}

A performance-goal or mastery orientation describes a student's inner wish to perform well academically. It supports a studious attitude and inner motivation, which enhance the probability of achieving better academic performance (Button et al., 1996; Chen and Mathieu, 2008; Roebken, 2007) and realizing better results. Students who are stirred by goal orientation are more organized and focused on their tasks and achieving their learning aims and final results. It inspires them to deploy more energy and mental efforts to their studying. Thus, we hypothesize:

H7: A high level of performance goal orientation increases students' academic achievement.

\section{Academic achievement}

Academic performance usually appears in research into education and educational psychology. Two main approaches offer different visions of academic performance. Approaching a specific goal is the most common method to assess academic performance, but avoiding adverse outcome offers an alternative (Valle et al., 2009; Was, 2006). Goal achievement might be focused on the task or end results (Valle et al., 2009; Was, 2006). By considering Facebook usage as a leisure activity that interferes with students' academic performance, we presume an effect on their overall academic results. Thus, our conceptualization of academic achievement is results focused and addresses only the final results/grades of the students.

\section{Role of polychronicity}

Polychronicity occurs across cultures; people from different cultures have different multitasking skills. Although people from Arabian and Middle Eastern countries (group 1) generally have the capability to work comfortably on two or more tasks and organize the different tasks they perform, people from European countries (group 2) would rather perform and work more efficiently on one task at a time. This tendency reflects the cultural background of each group (Usunier and Valette-Florence, 2007). Despite their different loadprocessing approaches, people are subject to the same working memory load. The priority 
that the former group gives to the performed task is not the only performance determinant; the interaction is more important. For the latter group, priority is given to tasks and time management (Usunier and Valette-Florence, 2007).

People with polychronicity skills can easily undertake two or more tasks simultaneously, through their ability to balance the allocated mental effort to different tasks. Thus, their cognitive load and working memory processing are balanced and might not increase excessively. In turn, talented multitasking students should be more effective in the different tasks they perform, and we test the following hypothesis:

H8a: Students with a high level of multitasking capabilities do not experience the presumed negative effect of Facebook use on their achievement.

$H 8 b$ : Students with a high level of multitasking capabilities do not experience the presumed negative effect of cognitive absorption on their achievement.

\section{Methodology}

To test the proposed research model, an empirical study was conducted with undergraduate students from Luleå University of Technology (LTU) in Sweden, to analyze the use of Facebook and its impact on the students in the Swedish context. A questionnaire was designed to address this particular focus and mapped to apply specifically to a Swedish educational context. Examples of the measures appear in Table 1. 
Table 1. Examples of Measures

\begin{tabular}{|c|c|c|c|}
\hline Constructs & Designation & Sample Measures & References \\
\hline $\begin{array}{l}\text { Social } \\
\text { Networking } \\
\text { Sites usage }\end{array}$ & $\begin{array}{l}\text { Facebook } \\
\text { usage }\end{array}$ & $\begin{array}{l}\text { How frequently do you use Facebook? } \\
\text { How much time do you spend on Facebook? }\end{array}$ & Teo et al. (1999) \\
\hline $\begin{array}{l}\text { Satisfaction } \\
\text { With Life }\end{array}$ & SWL & In most ways, my life is close to my ideal. & Diener et al. (1985) \\
\hline $\begin{array}{l}\text { Cognitive } \\
\text { Absorption }\end{array}$ & $\mathbf{C o g} \mathbf{A b}$ & $\begin{array}{l}\text { Temporal Dissociation } \\
\text { Time appears to go by very quickly when I } \\
\text { am using the Web. } \\
\text { Focused Immersion } \\
\text { While using the Web, I am absorbed in what I } \\
\text { am doing. }\end{array}$ & $\begin{array}{l}\text { Agarwal \& } \\
\text { Karahanna (1990) }\end{array}$ \\
\hline $\begin{array}{l}\text { Student } \\
\text { Achievement }\end{array}$ & St Ach & Grade point average (GPA) & $\begin{array}{l}\text { Appleton et al. } \\
\text { (2006); Karpinski \& } \\
\text { Duberstein (2009) }\end{array}$ \\
\hline $\begin{array}{l}\text { Personality } \\
\text { traits }\end{array}$ & Personality & $\begin{array}{l}\text { Extraversion } \\
\text { I see my self as extraverted, enthusiastic } \\
\text { Conscientiousness } \\
\text { I see my self as dependable, self-disciplined } \\
\text { Neurotic } \\
\text { I see my self as anxious, easily upset } \\
\text { Openess to change } \\
\text { I see myself as open to new experience, } \\
\text { complex } \\
\text { Agreeableness } \\
\text { I see myself as sympathetic, warm }\end{array}$ & $\begin{array}{l}\text { Gosling, Rentfrow } \\
\text { \& Swann }(2003)\end{array}$ \\
\hline Self-regulation & Selfreg & $\begin{array}{l}\text { Most of the time I pay attention to what I am } \\
\text { doing. } \\
\text { I think a lot about how I'm doing. }\end{array}$ & $\begin{array}{l}\text { Brown, Miller \& } \\
\text { Lawendowski (1999) }\end{array}$ \\
\hline Trust & Trust & $\begin{array}{l}\text { Most people answer personal questions } \\
\text { honestly. } \\
\text { Most people are honest in describing their } \\
\text { experiences and abilities. }\end{array}$ & $\begin{array}{l}\text { Kanawattanachai \& } \\
\text { Yoo }(2002)\end{array}$ \\
\hline $\begin{array}{l}\text { Performance- } \\
\text { goal } \\
\text { Orientation }\end{array}$ & PoG & $\begin{array}{l}\text { I prefer to do things that I can do well rather } \\
\text { than things that I do poorly. } \\
\text { I'm happiest when I perform tasks on which I } \\
\text { know that I won't make any errors. }\end{array}$ & Button et al. (1996) \\
\hline
\end{tabular}




\section{Data collection}

A paper-based survey collected data from LTU undergraduate students. Students received the surveys during one of their lectures and were asked to return them to the same lecturer during the next session. Thus the students had an interval, ranging from three days to one week, to answer the survey. Participation was voluntary for all students, and their motivation was enhanced by entering them in a drawing for three smartphones. Students from three majors participated: business administration, social sciences, and engineering. Ultimately, 239 completed surveys were collected, representing an approximately 30\% response rate.

\section{Results and Discussion}

The structural equation modeling used SmartPLS software, which can run the whole model and test interdependencies. It also supported a simultaneous test of the moderating effect. This section presents the results for the measurement model, followed by the structural model results and analysis.

\section{Measurement model}

The constructs in the model have different psychometric characteristics and are measured by reflective measures, represented by either a full scale or a set of dimensions that have been measured using corresponding scales, also with reflective measures.

Convergent validity. An exploratory factor analysis (EFA) of the reflective scales helped ensure the internal validity of constructs and dimensions (i.e., convergent validity). The EFA was run first with SPSS 18; the results were confirmed through the corresponding factor loadings on SmartPLS. Each item loading was significantly greater than 0.5, which indicated strong correlations with the corresponding constructs. Table 2 summarizes the psychometric characteristics of the constructs. 
Table 2. Psychometric properties: Factor loadings, AVE, and Cronbach's Alpha

\begin{tabular}{|c|c|c|c|}
\hline Constructs & Measures & Loadings & T Statistics \\
\hline \multirow{2}{*}{$\begin{array}{l}\text { Personality trait Orientation } \\
\text { AVE: } 0.74 \alpha=0.65\end{array}$} & Extrav & 0.85 & 8.16 \\
\hline & Openne & 0.87 & 12.75 \\
\hline \multirow{8}{*}{$\begin{array}{l}\text { Performance-Goal Orientation } \\
\text { AVE: } 0.54 \alpha=0.88\end{array}$} & PGO1 & 0.72 & 4.44 \\
\hline & PGO2 & 0.78 & 4.34 \\
\hline & PGO3 & 0.76 & 4.40 \\
\hline & PGO4 & 0.77 & 4.10 \\
\hline & PGO5 & 0.79 & 4.42 \\
\hline & PGO6 & 0.61 & 3.42 \\
\hline & PGO7 & 0.74 & 4.35 \\
\hline & PGO8 & 0.68 & 3.91 \\
\hline \multirow{3}{*}{ Polychronicity AVE: $0.61 \alpha=0.70$} & Pol1 & 0.80 & 3.63 \\
\hline & Pol2 & 0.94 & 4.13 \\
\hline & Pol3 & 0.56 & 2.32 \\
\hline \multirow{5}{*}{ Self-Regulation AVE: $0.62 \alpha=0.85$} & Eva & 0.80 & 10.33 \\
\hline & $\operatorname{Rec}$ & 0.84 & 10.55 \\
\hline & Ass & 0.81 & 12.71 \\
\hline & $\mathrm{Pla}$ & 0.77 & 8.47 \\
\hline & Tri & 0.72 & 8.40 \\
\hline \multirow{5}{*}{$\begin{array}{l}\text { Satisfaction with Life } \\
\text { AVE: } 0.50 \alpha=0.82\end{array}$} & LS1 & 0.65 & 3.15 \\
\hline & LS2 & 0.66 & 3.61 \\
\hline & LS3 & 0.79 & 4.31 \\
\hline & LS4 & 0.63 & 4.02 \\
\hline & LS5 & 0.85 & 5.24 \\
\hline \multirow{5}{*}{ Trust AVE: $0.53 \alpha=0.82$} & $\operatorname{Tr} 1$ & 0.67 & 3.87 \\
\hline & $\operatorname{Tr} 2$ & 0.68 & 3.89 \\
\hline & $\operatorname{Tr} 4$ & 0.81 & 6.33 \\
\hline & $\operatorname{Tr} 5$ & 0.73 & 5.92 \\
\hline & Tr6 & 0.83 & 5.68 \\
\hline
\end{tabular}

The purified scales in Table 2 show that the constructs are well represented by their corresponding items, as indicated by the loadings greater than 0.5 . The Cronbach's alpha values are greater than or approaching 0.7 for all constructs. Table 2 also confirms the convergent validity with the average variance explained (AVE), for which the values are all equal to or greater than 0.5 (Fornell and Larcker, 1981). Thus, the purified items measure their corresponding dimensions and constructs well.

The explained percentages $\left(\mathrm{R}^{2}\right)$ of the dependent variables (Facebook use, cognitive absorption, satisfaction with life, student's academic achievement) show that Facebook use is well explained by cognitive absorption $\left(\mathrm{R}^{2}=22 \%\right)$ combined with personality traits, self- 
regulation, and trust in people. This percentage helps explain students' long hours on these networking sites and engagement in this online social activity.

By focusing on Facebook usage (use and cognitive absorption), satisfaction with life, and performance goal orientations, this proposed model can explain $15 \%$ of the impact on students' academic achievement. Although not high, this percentage is notable. Facebook use and cognitive absorption can be explained at only low levels (5\% and $4 \%$, respectively), such that presence on social networking sites cannot be explained solely by personality traits, selfregulation, or trust. Cultural backgrounds, need for interaction, and platform interface features also help clarify students' immersion.

Discriminant validity. The PLS cross-loadings (see Table 3) indicate that each item measures its corresponding construct well, rather than other constructs. All the items are more correlated with their respective constructs than with other constructs in the model. In addition, the comparison of the square root of the AVE values to the correlation of the constructs with the rest of the constructs in Table 4 confirms the discriminant validity of the constructs, because the values of the square root of the AVEs are higher than the correlations.

Table 3. Cross-loadings

\begin{tabular}{|c|r|r|r|r|r|r|}
\hline & Personality & \multicolumn{1}{c|}{ SWL } & \multicolumn{1}{c|}{ PgO } & \multicolumn{1}{c|}{ Pol } & \multicolumn{1}{c|}{ Selfreg } & \multicolumn{1}{c|}{ Trust } \\
\hline Extrav & $\mathbf{0 . 8 5}$ & 0.21 & 0.21 & -0.10 & 0.28 & -0.02 \\
\hline Openne & $\mathbf{0 . 8 7}$ & 0.13 & 0.14 & -0.14 & 0.32 & 0.02 \\
\hline LS1 & 0.28 & $\mathbf{0 . 5 7}$ & 0.14 & 0.03 & 0.20 & 0.15 \\
\hline LS2 & 0.21 & $\mathbf{0 . 6 1}$ & 0.13 & 0.02 & 0.23 & 0.25 \\
\hline LS3 & 0.28 & $\mathbf{0 . 7 4}$ & 0.21 & -0.04 & 0.22 & 0.20 \\
\hline LS4 & 0.18 & $\mathbf{0 . 6 7}$ & 0.18 & -0.09 & 0.20 & 0.12 \\
\hline LS5 & 0.07 & $\mathbf{0 . 8 9}$ & 0.15 & -0.02 & 0.15 & 0.14 \\
\hline PGO1 & 0.20 & 0.24 & $\mathbf{0 . 7 2}$ & 0.10 & 0.41 & 0.17 \\
\hline PGO2 & 0.07 & 0.14 & $\mathbf{0 . 7 8}$ & 0.07 & 0.23 & 0.16 \\
\hline PGO3 & 0.23 & 0.27 & $\mathbf{0 . 7 6}$ & 0.01 & 0.36 & 0.20 \\
\hline PGO4 & 0.11 & 0.13 & $\mathbf{0 . 7 7}$ & 0.00 & 0.32 & 0.14 \\
\hline PGO5 & 0.20 & 0.11 & $\mathbf{0 . 7 9}$ & 0.06 & 0.28 & 0.11 \\
\hline PGO6 & 0.07 & 0.13 & $\mathbf{0 . 6 1}$ & 0.11 & 0.34 & 0.16 \\
\hline PGO7 & 0.11 & 0.15 & $\mathbf{0 . 7 4}$ & 0.01 & 0.36 & 0.11 \\
\hline PGO8 & 0.15 & 0.08 & $\mathbf{0 . 6 8}$ & 0.05 & 0.23 & 0.02 \\
\hline Pol1 & -0.20 & -0.06 & 0.00 & $\mathbf{0 . 8 0}$ & -0.08 & -0.02 \\
\hline Pol2 & -0.08 & -0.01 & 0.05 & $\mathbf{0 . 9 4}$ & -0.06 & 0.04 \\
\hline Pol3 & -0.10 & -0.02 & 0.08 & $\mathbf{0 . 5 6}$ & 0.09 & 0.04 \\
\hline Ass & 0.24 & 0.20 & 0.37 & -0.03 & $\mathbf{0 . 8 1}$ & 0.02 \\
\hline Eva & 0.27 & 0.19 & 0.44 & 0.00 & $\mathbf{0 . 8 0}$ & 0.07 \\
\hline Rec & 0.28 & 0.18 & 0.26 & -0.08 & $\mathbf{0 . 8 4}$ & 0.13 \\
\hline Pla & 0.35 & 0.31 & 0.27 & -0.07 & $\mathbf{0 . 7 7}$ & 0.05 \\
\hline
\end{tabular}




\begin{tabular}{|c|r|r|r|r|r|r|}
\hline Tri & 0.25 & 0.04 & 0.34 & -0.01 & $\mathbf{0 . 7 2}$ & 0.00 \\
\hline Tr1 & 0.00 & 0.22 & 0.16 & 0.03 & 0.07 & $\mathbf{0 . 6 7}$ \\
\hline Tr2 & -0.02 & 0.20 & 0.03 & -0.06 & -0.01 & $\mathbf{0 . 6 8}$ \\
\hline Tr4 & -0.01 & 0.15 & 0.12 & 0.05 & 0.03 & $\mathbf{0 . 8 1}$ \\
\hline Tr5 & -0.04 & 0.13 & 0.05 & 0.01 & 0.02 & $\mathbf{0 . 7 3}$ \\
\hline Tr6 & 0.03 & 0.12 & 0.18 & 0.01 & 0.12 & $\mathbf{0 . 8 3}$ \\
\hline
\end{tabular}

Table 4. Discriminant validity

\begin{tabular}{|l|r|r|r|r|r|r|}
\hline & Personality & PgO & \multicolumn{1}{l|}{ Pol } & SWL & Selfreg & Trust \\
\hline Personality & $\mathbf{0 . 8 6}$ & 0 & 0 & 0 & 0 & 0 \\
\hline PgO & 0.20 & $\mathbf{0 . 7 3}$ & 0 & 0 & 0 & 0 \\
\hline Pol & -0.14 & 0.05 & $\mathbf{0 . 7 8}$ & 0 & 0 & 0 \\
\hline SWL & 0.20 & 0.21 & -0.03 & $\mathbf{0 . 7 1}$ & 0 & 0 \\
\hline Selfreg & 0.35 & 0.42 & -0.05 & 0.23 & $\mathbf{0 . 7 9}$ & 0 \\
\hline Trust & 0.00 & 0.18 & 0.03 & 0.20 & 0.08 & $\mathbf{0 . 7 5}$ \\
\hline
\end{tabular}

All the reflective constructs (personality traits, self-regulation, trust, Facebook use, cognitive absorption, life satisfaction, polychronicity, and performance goal orientation) thus exhibit convergent and discriminant validity.

\section{Structural Model}

The internal validity of the constructs also can be confirmed by the convergent content validity of the scales. Their external validity is established in the form of discriminant validity; each item measures its corresponding construct consistently, rather than other constructs in the model. Therefore, we analyzed the interdependencies in the model by examining the path and total effects.

Path analysis. The path analysis (Table 5) indicates that personality traits (extraversion and openness to change) significantly affect time spent on the networking site $(\mathrm{pc}=0.23, \mathrm{~T}=3.82)$, but not immersion $(\mathrm{pc}=0.03, \mathrm{~T}=0.58)$ by students while surfing and interacting on the platform. Extraverted and open personality traits are significant characteristics of students who use Facebook the most (AVE $=0.74, \alpha=0.65$ ). Agreeable, 
conscientious, and neurotic students are minimally represented in the sample, so it was not possible to study the nature of their presence or activities on Facebook. The results based on perceived impact partially confirm the results presented in prior exploratory studies by Kaspernski and Duberstein (2009) and Canales et al. (2009). Finally, self-regulated students, in accordance with expectations about conscientious students, limit their presence on and usage of these sites.

Table 5. Path coefficients_-Direct effects

\begin{tabular}{|c|c|c|c|}
\hline Path coefficients (pc) & $\begin{array}{l}\text { Original } \\
\text { Sample }\end{array}$ & $\begin{array}{c}\mathbf{T} \\
\text { Statistics }\end{array}$ & Hypotheses \\
\hline Personality $->$ CogAbs & 0.03 & 0.58 & H1a: Rejected \\
\hline Personality -> Fuse & $0.23 * *$ & 3.82 & H1b: Accepted \\
\hline Selfreg -> CogAbs & $0.14 *$ & 1.92 & H2a: Accepted \\
\hline Selfreg -> Fuse & $-0.17 * *$ & 2.49 & H2b: Accepted \\
\hline Trust $->$ CogAbs & 0.11 & 1.51 & H3a: Rejected \\
\hline Trust -> Fuse & $-0.10 *$ & 1.76 & H3b: Accepted \\
\hline Fuse -> St Achi & $-0.14 * *$ & 2.14 & H4a: Accepted \\
\hline CogAbs -> St Achi & $-0.22 * *$ & 3.43 & H4b: Accepted \\
\hline CogAbs $->$ Fuse & $0.41 * *$ & 6.51 & H5: Accepted \\
\hline CogAbs $->$ SWL & $-0.16 * *$ & 2.04 & H6a1: Accepted \\
\hline Fuse -> SWL & 0.04 & 0.70 & H6a2: Rejected \\
\hline SWL -> St Achi & 0.09 & 1.55 & H6b: Rejected \\
\hline PgO -> St Achi & 0.10* & 1.92 & H7: Accepted \\
\hline CogAbs * Pol -> St Achi & $0.12 * *$ & 2.13 & H8a: Accepted \\
\hline Fuse * Pol -> St Achi & -0.07 & 1.22 & H8b: Rejected \\
\hline
\end{tabular}

Self-regulation significantly affects students' presence on Facebook $(\mathrm{pc}=-0.17, \mathrm{~T}=$ $2.49)$ and their immersion in this leisure activity $(\mathrm{pc}=0.14, \mathrm{~T}=1.92)$. However, trust in people does not significantly determine students' absorption in the online social networking activity, even as it significantly affects the time spent on Facebook. Students who trust other people may spend long hours interacting on Facebook, but they are not be cognitively immersed in this activity. Nor are they cognitively involved in the different tasks they perform.

Students' presence on the online networking site and their cognitive absorption negatively impact their academic achievement $(\mathrm{pc}=-0.14, \mathrm{~T}=2.14 ; \mathrm{pc}=-0.22, \mathrm{~T}=3.43$, respectively), according to the undergraduate students. Furthermore, the inability of some 
students to manage multitasks simultaneously increases their cognitive immersion in the task that attracts the most of their attention (i.e., surfing and Facebook interactions), but not the overall number of hours spent. In addition, satisfaction with life does not have a considerable effect on students' academic performance. These results indicate that Facebook use and interest enhance satisfaction with life, because they can catch up with friends, find older acquaintances, and get updates from friends and family members.

Meanwhile, performance goal orientation has a significant positive effect on students' achievements. Enhanced goal orientation refers to the desire and motives to learn, complete academic tasks, and acquire skills in problem solving and continuous academic development (Erez, 2005; McGrew, 2008), which push students to perform well in class and pursue academic achievement.

Finally, the total effects of social networking site usage and cognitive absorption on students' achievement (see Table 6) demonstrate the influence of the hypothesized factors (self-regulation, performance goal orientation, polychronicity, and satisfaction with life) on the presumed negative effect of networking platforms on academic achievement.

Table 6. Total effects

\begin{tabular}{|l|l|l|}
\hline Total effects & Path coefficients & T Statistics \\
\hline CogAbs -> Fuse & $0.41^{* *}$ & 6.51 \\
\hline CogAbs -> St Achi & $-0.29^{* *}$ & 5.08 \\
\hline Fuse -> St Achi & $-0.14^{* *}$ & 2.04 \\
\hline Personality -> Fuse & $0.25^{* *}$ & 4.04 \\
\hline Selfreg -> Fuse & $-0.12^{*}$ & 1.65 \\
\hline
\end{tabular}

The personality traits of extraverted and open students and self-regulation significantly determine the use of Facebook. In turn, Facebook use negatively affects students' academic performance $(\mathrm{pc}=-0.29, p<0.05)$. High cognitive immersion induces similar effects $(\mathrm{pc}=-0.14, p<0.05)$. In addition, cognitive absorption itself increases Facebook use ( $\mathrm{pc}=0.41, p<0.05)$, such that the more students are immersed and engaged in this platform, the more time they spend on it, at greater frequencies. 


\section{References}

Adan, L. (2011). Addicted to Facebook? Retrieved from: http://1batxeng.blogspot.se/2011/11/addicted-to-facebook.html. Last access: November $16,2011$.

Agarwal, R. \& Karahanna, E. (2000). Time flies when you're having fun: Cognitive absorption and beliefs about information technology usage. Management Information System Quarterly (MISQ), 24(4), 665-694.

Agarwal, R. and Karahanna, E. (2000). Time flies when you're having fun: Cognitive absorption and beliefs about information technology usage. Management Information System Quarterly (MISQ), 24(4), 665-694.

Ajzen I. \& Fishbein M. (1977). Attitude-behavior relations: A theoretical analysis and review of empirical research. Psychological Bulletin, 84, 888-918.

Appleton. J.J., Christenson, S.L., Kim, D. and Reschly, A.L. (2006). Measuring cognitive and psychological engagement: Validation of the Student Engagement Instrument. Journal of School Psychology, October, 44(5), 427-445.

Bagozzi, R.P. (1992). The self-regulation of attitudes, intentions, and behavior. Social Psychology Quarterly, 55, 178-204.

Barkley, R.A. (2001). The executive functions and self-regulation: An evolutionary neuropsychological perspective. Neuropsychology Review 11(1), 1-29.

Bastian, V.A., Burns, N.R., and Nettelbeck, T (2005). Emotional intelligence predicts life skills, but not as well as personality and cognitive abilities. Personality and Individual Differences, October 39(6), 1135-1145.

Blickle, G. (1996). Personality traits, learning strategies, and performances. European Journal of Personality, 10, 337-352. 
Boyd, D. \& Ellison, N. (2008). Social network sites: Definition, history and scholarship. Journal of Computer Mediated Communication, 13, 210-380.

Brown, J. M., Miller, W. R., \& Lawendowski, L. A. (1999). The Self-Regulation Questionnaire. in L. VandeCreek \& T. L. Jackson (Eds.), Innovations in clinical practice: A source book (Vol. 17, pp. 281-289). Sarasota, FL: Professional Resource Press.

Burke, M., Marlow, C., \& Lento, T. (2010). Social network activity and social well-being. Proceedings CHI 2010, ACM Press.

Button, S.B. Mathieu, J.E. \& Zajac, D.M (1996), Goal orientation in organizational research: A conceptual and empirical foundation. Organizational Behavior and Human Decision Processes, 67(1), 26-48

Canales, C., Wilbanks, B. \& Yeoman, A. (2009). Does Facebook have negative impacts on academic performance? Facebook usage in relation to personality and academic performance. Retrieved May 13, 2010 from http://www.covenant.edu/news/09.28.09.

Chen, G. \& Mathieu, J.E. (2008). Goal orientation dispositions and performance trajectories: The roles of supplementary and complementary situational inducements. Organizational Behavior and Human Decision Processes, May, 106 (1), 21-38.

Chen, L.H., Ye. Y-C, Chen, M-Y \& Tung, I-W. (2010). Alegria! Flow in leisure and life satisfaction: the mediating role of event satisfaction using data from an acrobatics show. Social Indicators Research, 99, 301-313.

Chow, H.P.H. (2010). Predicting academic success and psychological wellness in a sample of Canadian undergraduate students, Electronic Journal of Research in Educational Psychology, 8 (2), 473-496.

Clark, M. H., Schroth, C.A. (2010). Examining relationships between academic motivation and personality among college students. Learning and Individual Differences, 20(1), 1924. 
Csikszentmihalyi M. (1977). Beyond boredom and anxiety. San Francisco, CA: Jossey-Bass.

Csikszentmihalyi, M. \& Csikszentmihalyi, I. S. (1988). Optimal experience: Psychological studies of flow in consciousness. New York: Cambridge University Press.

Custodero, L. (2002). Seeking challenge, finding skill: Flow experience in music education. Arts Education and Policy Review, 103(3), 3-9.

Danielsen, A., Samdal, O., Hetland, J. \& Wold, B. (2009). School-related social support and students' perceived life satisfaction. Journal of Educational Research, 102(4), 303-320.

De Raad, B., \& Schouwenburg, H.C. (1996). Personality in learning and education: a review. European Journal of Personality 10, 303-336.

Devaraj, S., Easley, R., \& Crant, J. (2008). How does personality matter? Relating the fivefactor model to technology acceptance and use. Information Systems Research, 19(1), 93-105.

Diener, E. Emmons R.A, Larsen, R.J. and Griffin, S. (1985). The satisfaction with life scale. Journal of Personality Assessment, 49 (1), 71-75.

Doney, P.M. Cannon, J.P. \& Mulien, M.R. (1998). Understanding the influence of national culture on the development of trust. Academy of Management Review, 23(3), 601-620.

Egbert, H. (2004). Networking and entrepreneurial success: A case study from Tanga, Tanzania. In K. Wohlmuth, M. Meyn, A. Gutowski, T. Knedlik, \& S. Pitamber (Eds.), African entrepreneurship and private sector development (pp 291-309).

Ellison, N.B. Steinfield, C. \& Lampe, C. (2007). The benefits of Facebook "friends:" Social capital and college students' use of online social network sites. Journal of ComputerMediated Communication, 12(4). Retrieved: February 15, 2011 from http://jcmc.indiana.edu/vol12/issue4/ellison.html. 
Ellison, N.B., Steinfield, C. \& Lampe, C. (2011). Connection strategies: Social capital implications of Facebook-enabled communication practices. New Media \& Society. XX(X): 1-20. DOI: 10.1177/1461444810385389.

Erez, M., (2005). Goal-setting, goal-orientation. In N. Nicholson, P. Audia, \& M. Pillutla Eds.). Blackwell Encyclopedic Dictionary of Organizational Behavior, 2nd Ed. (pp 138141). Oxford, UK: Blackwell.

Facebook, (2011). I can't stop using Facebook, groups. Retrieved from: https://www.facebook.com/search/results.php?q=I\%20can\%27t\%20stop\%20using\%20fa cebook\&init=quick\&tas=0.876909596566064. Last access: October 12, 2011.

Finneran, C.M. \& Zhang, P. (2003). A person-artefact-task (PAT) model of flow antecedents in computer-mediated environments. International Journal of Human-Computer Studies, 10 (59), 475-496.

Fogg, B. J., \& Iizawa, D. (2008). Online persuasion in Facebook and Mixi: A cross-cultural comparison. Lecture Notes in Computer Science. (pp 35-46).

Fornell, C., \& Larcker, D. F. (1981). Evaluating structural equation models with unobservable variables and measurement error. Journal of Marketing Research, 18, 3950.

Furnham, A., Petrides, K. V., Sisterson, G. \& Baluch, B. (2003). Repressive coping style and positive self-presentation. British Journal of Health Psychology, 8, 223-249.

Ginger, J. (2007). The Facebook project: Cyborging of the mind in a permanently beta digital ecology. The Facebook Project.com. Retrieved: June 2, 2011 from http://thefacebookproject.com/research/jeff/publications/masters.html.

Golbeck, J. (2009). Trust and nuanced profile similarity in online social networks. ACM Transactions on the Web, 3(4). Article 12. 
González, A.E.M. , Saura, C.J.I ., Rodríguez, J.A.P. and Linares V.R.L. (2010). The importance of friends and parents in health and academic performance. Electronic Journal of Research in Educational Psychology, 8(1), 111-138.

Gosling, S. D., Rentfrow, P. J., \& Swann, W. B., Jr. (2003). A very brief measure of the big five personality domains. Journal of Research in Personality, 37, 504-528.

Grabner-Krauter, S. \& Kaluscha, E. (2003). Empirical research in on-line trust: a review and critical assessment. International Journal of Human Computer Studies, 58, 783-812.

Grandison T. \& Sloman, M. (2000). A survey of trust in Internet applications. IEEE Communications and Surveys, Fourth quarter. Retrieved June 11, 2011 from http://www.comsoc.org/pubs/surveys.

Hardie, E. \& Tee, M. Y. (2007). Excessive Internet use: The role of personality, loneliness and social support networks in Internet addiction. Society, 5(1), 34-47. Retrieved March 02, 2011 from http://hdl.handle.net/1959.3/5548.

Hofstede, (1984). Culture's Consequences, International Differences in Work-Related Values. Cross Cultural Research and Methodology Series. SAGE Publications.

Hofstede, G. \& Hofstede, G.J. (2005) Cultures and organizations: Software of the mind. New York: McGraw-Hill editions.

Hofstede, G. (2010). The GLOBE debate: Back to relevance. Journal of International Business Studies, 41 (8), 1339-1346.

Huang, C-Y. \& Carleton, B. (2003). The relationships among leisure participation, leisure satisfaction, and life satisfaction of college students in Taiwan. Journal of Exercise Science and Fitness, 1(2), 129-132.

Huebner, E. S. (2004). Research on assessment of life satisfaction of children and adolescents. Social Indicators Research, 66, 3-33, 2004. 
Huebner, E. S., Laughlin, J. E., Ash C., \& Gilman, R. (1998) Further validation of the multidimensional students' life satisfaction scale. Journal of Psychological Assessment, $16,118-134$.

Inside Facebook Gold (2011), Audience growth on Facebook: Top 25 country markets. Retrieved June 15, 2011 from http://gold.insidenetwork.com/facebook/facebook-stats/.

Internet World Stats, $2010 \quad$ Retrieved $\quad$ May, $15 \quad 2011$ from http://www.internetworldstats.com/stats.htm.

Jackson, S.F., Cleverly, S., Poland, B., Robertson, A., Burman, D., Goodstadt, M. \& Salsberg, L. (1997). Half full or half empty?: Concepts and research design for a study of indicators of community capacity. Research report North York Community Health Promotion Research Unit, North York, Ontario.

Jarvenpaa, S.L. Tractinsky, N. \& Vitale, M (2000). Consumer trust in an Internet store. Journal of Information Technology and Management, 1(1-2), 45-71.

Jarvenpaa, S.L., Tractinsky, N. \& Saarinen' L. (1999). Consumer trust in an Internet Store: A cross-cultural validation. Journal of Computer-Mediated Communication, December, $5(2)$.

Judge, T.A., Higgins, C.A., Thoresen, C.J. \& Barrick, J. R. (1999). The Big Five personality traits, general mental ability, and career success across the lifespan. Personnel Psychology, 52, 621-652.

Kamdar, D., \& Van Dyne, L. (2007). The joint effects of personality and workplace social exchange relationships in predicting task performance and citizenship performance. Journal of Applied Psychology, 92, 1286-1298.

Kanawattanachai, P. and Yoo, Y. (2002). Dynamic nature of trust in virtual teams. The Journal of Strategic Information Systems, December, 11 (3-4), 187-213.

Kangas, P., Toivonen, A. \& Bäck, A. (2007). Ads by Google and other social media business models. VTT research notes 2384 . 
Karpinski, A.C. \& Duberstein, A. (2009). A description of Facebook use and academic performance among undergraduate and graduate students. American Educational Research Association (AERA) Conference, San Diego, 13-17 April.

Kiesler, S. (1997). Culture of the Internet. Mahwah, NJ: Lawrence Erlbaum Associates.

Koufaris, M. (2002). Applying the technology acceptance model and flow theory to online consumer behavior. Information Systems Research, 13(2), 205-223.

Latham, G.P. \& Locke, E.A. (1991). Self-regulation through goal setting. Organizational Behavior and Human Decision Processes, 50, 212-247

Leung, J.P., \& Leung, K. (1992). Life satisfaction, self-concept, and relationship with parents in adolescence. Journal of Youth and Adolescence, 21, 653-665.

Lolle, H. \& Torpe, L. (2010). Ethnic diversity and social trust in Denmark and Sweden. In Bengtsson, Bo, Strömblad, Per and Bay, Ann-Helen, (Editors). Diversity, Inclusion and Citizenship in Scandinavia. Cambridge Scholars Publishing, Newcastle upon Tyne.

Lolle, H. \& Torpe, L. (2011). Growing ethnic diversity and social trust in European societies. Comparative European Politics, 9(2), 191-216.

Lounsbury J.W., Saudargas, R.A., Gibson, L.W. \& Leong, F.T. (2005). An investigation of broad and narrow personality traits in relation to general and domain-specific life satisfaction of college students. Research in Higher Education, 46(6), 707-729.

Lu, H-P, Lin, J. C-C, Hsiao, K-L. \& Cheng, L-T. (2010). Information sharing behavior on blogs in Taiwan: Effects of interactivities and gender differences. Journal of Information Science. June, 36(3), 401-416.

McGrew, K. (2008). Beyond IQ: A model of academic competence \& motivation (MACM). Retrieved March 12 , 2011 , http://www.iapsych.com/acmcewok/Achievementgoalorientation.html. 
Nazir, A., Raza, A., Gupta, D., Cuhuah, C.N. \& Krishnamurthy, B. (2009). Network level footprints of Facebook applications. In Proceedings of the 9th ACM SIGCOMM conference on Internet Measurement Conference (IMC'09), Chicago, Illinois.

Novak, T.P., Hoffman, D.L. \& Yung, Y-F. (1998). Modeling the structure of the flow experience among web users. INFORMS Marketing Science and the Internet MiniConference, MIT, March, 15 pages.

O’Neill, K. (1999b), Internetworking for social change: Keeping the spotlight on corporate responsibility. Discussion Paper No. 111, United Nations Research Institute for Social Development (UNRISD), Geneva.

Olver, J.M. \& Mooradian, T.A. (2003), Personality traits and personal values: a conceptual and empirical investigation, Personality and Individual Differences, 35(1), 109-125.

O'Neill, K. (1999a). Flow theory and the development of musical performance skills. Bulletin of the Council for Research in Music Education, 141, 129-134.

Pace, S. (2004). A grounded theory of the flow experiences of web users. International Journal of Human-Computer Studies, March, 60 (3), 327-363.

Poropat, A. E. (2009). A meta-analysis of the five-factor model of personality and academic performance. Psychological Bulletin, 135(2), 322-338.

Posner, M. I. \& Rothbart, M. K. (1998). Attention, self-regulation, and consciousness. Philosophical Transactions of the Royal Society of London, 353, 1915-1927.

Posner, M. I., \& Rothbart, M. K. (2000). Developing mechanisms of self-regulation. Development and Psychopathology, 12, 427-441.

Robbins, S. P., \& Judge, T. A. (2011). Organizational behavior, $14^{\text {th }}$ Ed. Upper Saddle River, NJ: Pearson/Prentice Hall.

Roccas, S., Sagiv, L., Schwartz, S. H. \& Knafo, A. (2002). The Big Five personality factors and personal values. Personality and Social Psychology Bulletin, 28, 789-801. 
Roccas, S., Sagiv, L., Schwartz, S. H., Halevy, N. \& Eidelson, R. (2008). Towards a unifying model of identification with groups: integrating theoretical perspectives. Personality and Social Psychology Review, 12, 280-306.

Roebken, H. (2007). The influence of goal orientation on student satisfaction academic engagement and achievement, Electronic Journal of Research in Educational Psychology, 5 (3), 1696-2095

Rouis, S. (2012). Impact of Cognitive Absorption on Facebook on Students' Achievement. Cyberpsychology, Behaviour and Social Networking, forthcoming.

Schulten, K. (2009a). Do You Spend Too Much Time on Facebook?. Retrieved from: http://learning.blogs.nytimes.com/2009/12/21/do-you-spend-too-much-time-onfacebook/\#comment-6325. Last access: September 07, 2011.

Schulten, K. (2009b). The learning network blog. Retrieved June 10, 2011, http://learning.blogs.nytimes.com/2009/12/21/do-you-spend-too-much-time-onfacebook/.

Shernoff, D. J., Csikszentmihalyi, M., Schneider, B. \& Shernoff, E. S. (2003). Student engagement in high school classrooms, from the perspective of flow theory. School Psychology Quarterly. 18, 158-176.

Smith, D. N. \& Sivakumar, K. (2004). Flow and Internet shopping behavior: A conceptual model and research propositions. Journal of Business Research, 57(10), 1199-1208.

Suldo, S. M., Shaffer, E. J. \& Riley, K. N. (2008). A social-cognitive-behavioral model of academic predictors of adolescents' life satisfaction. School Psychology Quarterly, 23(1), 56-69.

Suldo, S.M., Riley, K.N. \& Shaffer, E.J. (2006). Academic correlates of children and adolescents' life satisfaction. School Psychology International, 27(5), 567-582.

Tabak, F., Nguyen, N., Basuray, T. \& Darrow, W. (2009). Personality and individual differences exploring the impact of personality on performance: How time-on-task 
moderates the mediation by self-efficacy. Personality and Individual Differences, 47, $823-828$.

Teo, T.S.H., Lim, V.K.G. and Lai, R.Y.C (1999). Intrinsic and extrinsic motivation in Internet usage. Omega, February, 27(1), 25-37.

Uslaner, E.M. \& Badescu, G. (2002). Honesty, trust, and legal norms in the transition to democracy: Why Bo Rothstein is better able to explain Sweden than Romania. Collegium Budapest Project on Honesty and Trust Conference, Workshop on Formal and Informal Cooperation, November 22-23, 2002. 50 pages.

Uslaner, E.M. (2000). Social capital and the Net. Proceedings of the ACM, 43, 60-64

Usunier, J.C. \& Valette-Florence P. (2007). The Time Styles Scale: A review of developments and replications: Over 15 years. Time \& Society, 16, 333-366.

Valle, A., Rodríguez, S., Cabanch, R.G., Núnez, J.C., González-Pienda, J.A. and Rosario, \& P. (2009). Academic goals: Historical and conceptual perspectives and educational implications. Electronic Journal of Research in Educational Psychology, 7(3), 10731106.

Vasalou, A. Joinson A.N. \& Courvoisier, D. (2010). Cultural differences, experience with social networks and the nature of "true commitment" in Facebook. International Journal of Human-Computer Studies, 68(10), 719-728.

Wang, Y.D. \& Emurian, H.H. (2005). An overview of online trust: concepts, elements, and implications. Computers in Human Behavior (21), 105-125.

Was, C. (2006). Academic achievement goal orientation: Taking another look. Electronic Journal of Research in Educational Psychology, 4(3), 1696-2095.

Yoder, C. \& Stutzman, F. (2011). Identifying social capital in the Facebook interface. ACM CHI Conference on Human Factors in Computing Systems CHI 2011, May 7-12, Vancouver, BC, Canada. 
Yoon, S.J. (2002). The antecedents and consequences of trust in on-line purchase decisions. Journal of Interactive Marketing, 12(2), 47-63.

Young, S. Dutta, D. \& Dommety, G. (2009). Extrapolating psychological insights from Facebook profiles: a study of religion and relationship status. CyberPsychology \& Behavior, 12 (3), 347-350. 